\title{
The Representation of (Illegal) Migrants in The British News
}

\author{
CAROLINA SILVEIRA Humboldt Universität Zu Berlin
}

\begin{abstract}
This research looks at how migration is represented in British newspapers by using multimodal critical discourse analysis (MCDA) to examine two news articles published in July/June 2015 from The Guardian and the Daily Mail. The study takes a closer look at the categories used to define immigrants, including the implicit assumption of illegality associated with 'migrants' crossing the Mediterranean/Calais. The analysis reveals how both news articles contribute to a similar discourse, which places the refugee at a distance and presents the UK as being threatened by a rising number of, specifically male, 'migrants'. This article deconstructs two ideologically dissimilar news articles to reveal the manner in which they can both contribute to a negative construction of refugees and immigrants arriving in Europe.
\end{abstract}

\section{KEYWORDS}

Europe, asylum seekers, illegal immigration, multimodal critical discourse analysis, British news

\section{Introduction}

The surge in 'migrants' trying to reach Britain has recently become a particularly problematized issue in the UK (BBC News 2015). Concerns with immigration have given rise to the popularity of far-right parties like UKIP, and to an adjustment of policies by mainstream parties like Labour, who even publicized their antiimmigration stance on coffee mugs during the 2015 general election campaign. Likewise, the 'threat' of mass migration to the UK consistently makes headline news in the British press (BBC 2015b; BBC 2015a; Swinford 2015; Whitehead 2015; The Guardian 2015b). A distinction is drawn between refugees and immigrants; the definition of the former refers to someone who leaves their country of residence due to 'a well-founded fear of being persecuted' (UNHCR 2011) and the latter divergently describes 'a person who moves to a country other than that of his or her usual residence $[\ldots .$.$] so that the country of destination effectively becomes his or her new$ country of usual residence' (The Migration Observatory 2015). However, these two categories are often inter-woven: refugees are often considered 'migrants' in datasets, and many who seek asylum may not be granted refugee status since a 'well-founded fear' of persecution remains subject to interpretation by the receiving country. In engaging with the political and social implications of migration discourses, this paper questions the assumptions that underlie the 'problem' of immigration and asylum. More concretely, the focus of this essay is the representation of refugees and asylum 
seekers who attempt to enter Britain through Calais/the Mediterranean. Two British news articles are taken as examples for a deeper analysis (The Guardian 2015c; Burleigh 2015). In the course of this paper, I will take a closer look at the categorization of immigrants, as both articles use the term 'migrants' to refer to refugees. First, my theoretical framework will be introduced before I present a short analysis of the discursive practice and social context, and subsequently, an analysis of the textual and visual elements.

\section{Theoretical and Methodological Framework}

Multimodal Critical Discourse Analysis (MCDA) has recently emerged as a way to apply a Critical Discourse Analysis framework to non-textual modes (i.e. pictures, videos, gestures, etc.). Influenced by semiotics, MCDA scholars (see for example: Machin \& Mayr 2012; Kress \& Van Leeuwen 1996; Bowcher 2007; Jones 2012; LeVine \& Scollon 2004) acknowledge the inter-related importance of both textual and visual modes. Much like its CDA predecessor, MCDA also aims to 'map three separate forms of analysis onto one another' (1995a, 2), which in this instance include both written and visual modes, discourse practices, and discursive events as instances of sociocultural practice. MCDA thus combines micro and macro textual analysis (Richardson 2007, 47) as well as iconographical/iconological analysis of visual images in order to explore 'the way that individual elements in images, such as objects and settings are able to signify discourses in ways that might not be obvious at an initial viewing' (Machin \& Mayr 2012, 31). This includes representation between actor and viewer (gaze, distance, angle); representation of different participants (categorization, non-representation, individual/group); representation of agency and action (Machin \& Mayr 2012, 117-125); and the 'grammar' of colour and visual design (Kress \& Van Leeuwen 1996; Kress \& Van Leeuwen 2002). Moreover, discourse practices and social practices must also be taken into account. Here, discourse practice refers to the production and consumption of texts, including the sets of conventions that place the text in a particular genre. The social practice of discourse is then the wider context, i.e. the institutions or sociocultural aspects that restrain some types of discourse, and promote hegemonic discourse.

In recent years, the representation of refugees in the media has been researched extensively in the UK (see: Baker 2007; Allen \& Blinder 2013; Philo et al. 2013; Zetter 2007; Turton 2003a), often pointing to the rather negative portrayal of refugees, asylum seekers or immigrants. As Zetter (2007) and Turton (2003) emphasize, we conceptualize the issue of refugee protection through socially constructed categories. For example, while immigrants from affluent countries are often categorised as 'expats', those from non-Western countries tend to be labelled 'economic migrants'. These labels and categories are not just part of a neutral bureaucratic process, they are 'formed and reformed as part of a social compact between the state and its citizens... keeping the refugees and other displaced people at a distance' (Zetter 2007, 190). However, despite migrants and migration being a constant object of investigation, this 'social making' of the 'migrant' is often depoliticized (Schweppe \& Sharma 2015). By placing discourse at the fore, scholars can re-politicize these labels, and point to real life consequences. For example, Goodman \& Speer (2007) provide insight into how negative imagery of asylum 
seekers in newspapers helps to legitimise the harsher treatment of refugees, while Philo et al. (2013) highlight the impact that the negative framing of asylum seekers has on public perceptions, on the lives of refugees, and on local communities. This paper builds on the existing literature by using multimodal discourse analysis to examine how both texts and images interact in constructing the discourse.

\section{Discursive Practices and Social Context}

It is important to keep in mind that discourse is produced within discursive practices that govern its rules and norms. In this research, the particular newspapers chosen have different ideological standpoints, different institutional practices, and different audiences. The Guardian is a broadsheet newspaper with a readership that leans towards the middle class, males, liberals, and a younger age group, and has been experiencing a decline in sales (Flashnews UK 2009). The newspaper has a more critical stance than other major papers, and leans to the left. Despite the decrease in sales, The Guardian remains one of the most widely read newspaper websites in the UK (Reid 2014). The Daily Mail, however, has an older readership, is right-wing leaning, and is somewhere between a tabloid and broadsheet newspaper. It is one of the most popular newspapers in the UK, and its online platform is also managing to attract a younger audience. This has arguably caused the paper to use more sensationalist journalism in their online version in order to attract and retain younger readers (Cunha 2013).

This information is relevant because it makes us aware of the possible aims of those producing the news. The question here then is: what are the discursive practices of both newspapers that relate to the way the articles are presented? If we look at how The Guardian manages its own image, we can see that it places a strong focus on integrity: The Guardian's website contains a section on their values, which includes the editorial code of their journalists, and their commitment to accuracy and high standards of reporting (The Guardian 2011). No similar page can be found on the Daily Mail website, although it is apparent, on the 'contact us' page (Daily Mail 2015), that readers may be an active participant in the production of news content, as they are invited to send in their own stories and photos. One could conclude from this that The Guardian is arguably fostering a reputation for higher quality news. With regard to the topic of immigration, The Guardian has had an explicitly more liberal view and often provides an alternative 'pro-immigration' stance. For example, in March, the website held an 'immigration special' day, on which it published several articles on the topic as a way to 'break the taboo around immigration' (The Guardian 2015a). On the opposite side of the scale is the Daily Mail, which in general tends to adopt a more restrictive stance, portraying refugees negatively and often conflating the categories of asylum seekers, migrants and refugees.

However, the confusion with regard to word choice is not limited to the Daily Mail; debates about which term to use have been on-going in the media. The Guardian, for example, questions the employment of the term 'Expat' to describe white 'Westerners' when other immigrants are often pejoratively labelled as 'economic migrants' (Koutonin 2015). The negative connotations of the word migrant have also been highlighted by Al Jazeera, which finds the word 'no longer fit for purpose when 
it comes to describing the horror unfolding in the Mediterranean' (Malone 2015). It would perhaps be more humane to describe 'migrants' simply as people, as David Marsh (2015) and Lindsey Hilsum (2015) suggest. Yet, Channel 4 news and The Guardian continue to use the word migrant in their news stories. According to Marsh and Hilsum, the problem does not lie in the word itself, but in discourses that dehumanise people who travel in search of a better life, discourses that propagate 'an agenda that says: migrants = bad' (Marsh 2015; Hilsum 2015). There is no consensus on the correct term to use - and understandably so, considering the complexity of defining the situation. On the one hand, one can argue that if the motive for migration is unknown, then the catch-all term 'migrant' is applicable; on the other hand, when we know that the vast majority of the people being talked about are in fact refugees, should we not refer to them as such? This is highlighted by Malone (2015), who observes that:

"There is no "migrant" crisis in the Mediterranean. There is a very large number of refugees fleeing unimaginable misery and danger and a smaller number of people trying to escape the sort of poverty that drives some to desperation.'

This essay does not provide a solution to this terminological dilemma; rather, it highlights the implications of the words chosen in the news articles in question. Considering the context of the news stories analysed here, namely the fact they are reporting on people who are risking their lives to cross the border, I am referring to them as 'refugees' or 'people' as opposed to 'migrants', unless directly referencing the language of the news articles.

In the wider social context, granting asylum has very much become conceptualised as a 'problem' for European countries, with a contradicting rhetoric of humanitarian protection versus security threats. It is perceived as a problem in humanitarian terms because 'we' have an obligation to help refugees - either in a moral sense or simply because of international treaties such as the Geneva Convention (Barnett 2002); it is discussed as a security problem because the arrival of large numbers of refugees is seen as a strain on the welfare system, housing, infrastructure, schools, etc., as well as detrimental to a country's national/ethnic culture. With the perceived threat that a rise in immigration can bring, it becomes more and more important for refugees to be able to prove their victimhood. International and European regulations governing the management of asylum flows contribute to the contemporary asylum regime, which is based on international obligations towards refugee protection. However, with new labels in the processing chain now preceding the 'refugee' status, i.e. 'asylum seeker', 'temporary protection', or 'irregular migrant', a hierarchy of suffering is constructed in which the refugee category is at the top, becoming akin to a 'prized status and expensive commodity' (Turton 2003b, 4). The nation state also plays a vital role in asylum discourse, as it can be simultaneously the creator and accommodator of refugees. Any discussion on immigration is inevitably situated in relation to the nation state, albeit with social constructs like citizenship and nationality often taken as a given rather than critically questioned.

It is impossible to ignore the harrowing context of current refugee discourses - many died in capsized boats as they attempted to enter Europe in the months prior to the 
news articles analysed here. Such tragedies have sparked debate in the UK over the rhetoric used to describe refugees. Most notably, David Cameron's recent and infamous description of a 'swarm' of migrants trying to enter Britain illegally (BBC News 2015), or comments by tabloid newspaper columnist Kate Hopkins who advocates the use of 'gunships to stop migrants...[they] are like cockroaches' (Hopkins 2015). Such language clearly connotes the idea that 'migrants' are nothing more than insects, and works to dehumanize the people being talked about, legitimizing their subhuman and murderous treatment. This contrasts starkly with the other side of the argument, exemplified in an editorial article in The Guardian: 'It makes sense that it should be easier for people to come in, so as to avoid such tragedies' (The Guardian 2014). Irregular migration into Europe by road is also perceived along similar lines: while one side, appearing to be the position of the Daily Mail, portrays refugees who 'smuggle themselves' into Europe as criminals (Massey et al. 2015), The Guardian tends to portray 'illegal' entry as a sometimes necessary last resort (Taylor 2015).

\section{Textual and Visual Analysis}

'Numbers of migrants crossing Mediterranean nearly doubles in a year' The Guardian, 1 July 2015

'Forget the Greek crisis or Britain's referendum, this tidal wave of migrants could be the biggest threat to Europe since the war'

Daily Mail, 26 June 2015

The word choice of the above headlines is an apt starting point for this textual analysis; both articles use the word 'migrant' to refer to what others might consider asylum seekers or refugees. The Guardian article in fact goes on to quote the UN refugee chief and talk about the refugee crisis, but still uses the somewhat more general term 'migrant' in the headline. As aforementioned, the labels used to conceptualise the problem of refugee protection are not neutral terms, they have political and social significance. Consider for example the term asylum seeker: it includes a verb, connoting action and agency, and implies that the status of the asylum claim is not resolved since if one is seeking something, it is not yet possessed. By contrast, the word refugee is passive, much like the words employee or detainee for example, as it requires a counterpart who employs, detains, or who gives refuge. There is an implicit vertical power relation as refugees are dependent on someone's help. The word 'migrant' on the other hand, excludes all of these nuances, omitting any possible reason for the migration, while retaining agency: a refugee needs refuge, an asylum seeker seeks asylum, but a migrant simply migrates, implying a freedom of choice. The Daily Mail article goes a step further by qualifying the 'migrants' crossing Calais as 'illegal', which also proves problematic. Recent debates over the term 'illegal' migrant/immigrant have, for example, pointed to the fact that such phrases are neither 'accurate nor neutral' descriptions, as a person cannot be illegal (Chauvin \& Garcés-Mascareñas 2014; Gambino 2015). Nonetheless, the adjective continues to be widely used in the media and even by the Home Office in the UK as it tries to 'make Britain a harder place for illegal migrants' (Brokenshire 2015). 
Another important aspect of the headlines is the representation of refugees as masses. In The Guardian, 'migrants' are very clearly presented in terms of increasing numbers, connoting the idea of invasion. Describing them as numbers helps to construct them as an undifferentiated mass rather than as individual humans. This serves as a distancing technique, which has implications for the way the reader responds to the headline. In the field of psychology for example, studies have shown that people tend to show greater empathy with one individual story rather than with a large number of victims (Ropeik 2011). Moreover, the reader is distanced from the events, as the article emphasises 'Southern Europe' and the 'Mediterranean' rather than the UK. We can see the increase in 'migrants' as a concern for 'us' (Britain) as Europeans and as a country geographically close to the Mediterranean, but we can also deflect the problem to countries in the south, with the logic that Europe ought to do something about this problem. Indeed, The Guardian seems to frame the issue as a European one throughout the article: it goes on to describe refugees as a 'heavy load' on European states, and to hail the EU's plan to 'redistribute 40,000 Syrian and Eritrean asylum seekers'. Such descriptions bring to the fore the uneven power relations between the EU and those outside its borders - asylum seekers are described here as a heavy burden for Europe, despite the fact that Europe only takes in an astoundingly small proportion of the word's refugees (developing countries outside of Europe currently host $86 \%$ of refugees (UNHCR 2015)). Moreover, the EU has the power to redistribute refugees at will, seemingly treating them as 'objects to be managed by the state', rather than as human beings (Melissaris 2016). The Guardian article fails to address the problematic of a EU policy that focuses on coercively moving asylum seekers from one member state to another (Lenart 2012) and on stopping refugees from even reaching the EU in the first place (Paul 2016), rather than on improving reception standards. Yet, the EU is hailed in The Guardian article as the solution to the Mediterranean crisis in regard to its search and rescue operations: with the right policy, backed by an effective operational response, it is possible to save more lives at sea. In this way, Europe is presented as both a victim, weighed down by the huge number of 'migrants' arriving at its borders, and as a saviour, heroically offering solidarity.

In the Daily Mail, the de-humanizing effect is amplified through the use of the metaphor 'tidal wave'. This not only portrays the refugees as an undifferentiated mass by equating them to a wave, but the magnitude of this mass is conveyed by the word 'tidal', in which the wave referred to is exceptionally large and associated with the idea of disaster. As David Turton elaborates, this technique allows us to distance ourselves from the situation as it can 'de-personalise, even de-humanise the people we are talking about' $(2003,5)$. The metaphor does more than convey a negative idea of asylum seekers, however; when we talk about a natural event we make certain presuppositions: natural events are not directly caused by us; they are a threat that is difficult to control; but that we cannot simply ignore, we must somehow defend ourselves against it; and of course, they occur naturally. The implications of this are tremendous. First, any responsibility that Europe may have in the creation of refugees, for example, through war or economic sanctions, is omitted. Second, the idea that this natural 'wave' will undoubtedly affect 'us' is embedded in certain discourses, including the supposed attractiveness of the UK in terms of welfare systems as a 'pull factor' for asylum seekers and migrants (Schulzek 2012), a factor which is also mentioned in the Daily Mail article. Third, in order to prepare for this inevitable 
natural threat, 'we' must incorporate measures that will keep this danger as far away as possible.

The 'us' and 'them' demarcation works on two levels; first, calling 'migrants' a 'threat to 'Europe' indirectly makes them a threat to European Britain. However, the headline also points to the Euro-sceptic tension in the UK, precisely by constructing the 'migrant crisis' as Europe's problem. This rhetoric continues throughout the Daily Mail article. A dichotomy emerges between Prime Minister David Cameron, presented as a defendant of British sovereignty, and EU leaders who are seemingly striving for 'an ever closer union'. The EU is presented as problematic for a variety of reasons: mandatory quotas for asylum applications for member states, 'political correctness', a general inability to 'get a grip on the problem', and EU migrants claiming benefits in the UK are just a few examples. Despite the strong Euroscepticism presented in the Daily Mail, however, the news article also portrays the EU as a potential hero in this crisis by offering a whole host of measures that could be employed by EU leaders, including: 'public information campaigns in the migrants' home countries' to discourage them from coming to Europe; 'draconian penalties for domestic employers of illegal migrant labour'; processing illegal migrants outside EU borders; and accelerating the 'process of repatriating failed asylum-seekers' so as to make it harder for them to appeal in the EU. Hyperboles are used to exaggerate the threat - the 'migration' problem is described as being 'wildly out of control', as Europe's 'most urgent problem', a 'catastrophe', and as 'appalling and anarchic'. By highlighting the supposed unruliness of the people crossing the border, the article employs a clash of civilizations discourse in which 'we' are the civilized, and 'they' are barbaric criminals. The portrayal of violence continues as the author describes the 'besieged lorry drivers', and 'migrants armed with knives', claiming that it is only a 'matter of time before someone [British] is killed'.

Despite the similarities of both articles, it is also important to note how they diverge. An important difference between them is their style - the Daily Mail uses sensationalist, emotionally evocative language. It makes stronger use of hyperboles and metaphors, and uses historical references that connote and equate tragedy ('since the war'). The Guardian, on the other hand, is devoid of such emotive language, keeping up the appearance of objectivity with a single-fact headline that, in simple terms, tells us that the numbers (of migrants) have doubled. The headline is in the present tense even though the data, i.e. the number of migrants, refers to the previous year. This makes the problem seem on-going, but also allows the author to speak with certainty - he already has the necessary facts. In the Daily Mail's headline, the modality is less certain ('could'), and more speculative since it refers to possible future events. However, the potential lack of certainty in the modality is somewhat out-weighed by the imperative mood of the sentence ('Forget...'), which imposes the authority of the author. Starting the sentence with such a command implies that the author is an expert, or at least knows more than the reader on this subject and can tell them the 'real' truth on the matter. Moreover, the headline refers to 'this' wave of 'migrants', suggesting that only recent migration is a problem. This nuance allows for British citizens with an immigration background to feel included in the 'we' of the article as only this 'wave' poses a threat. 


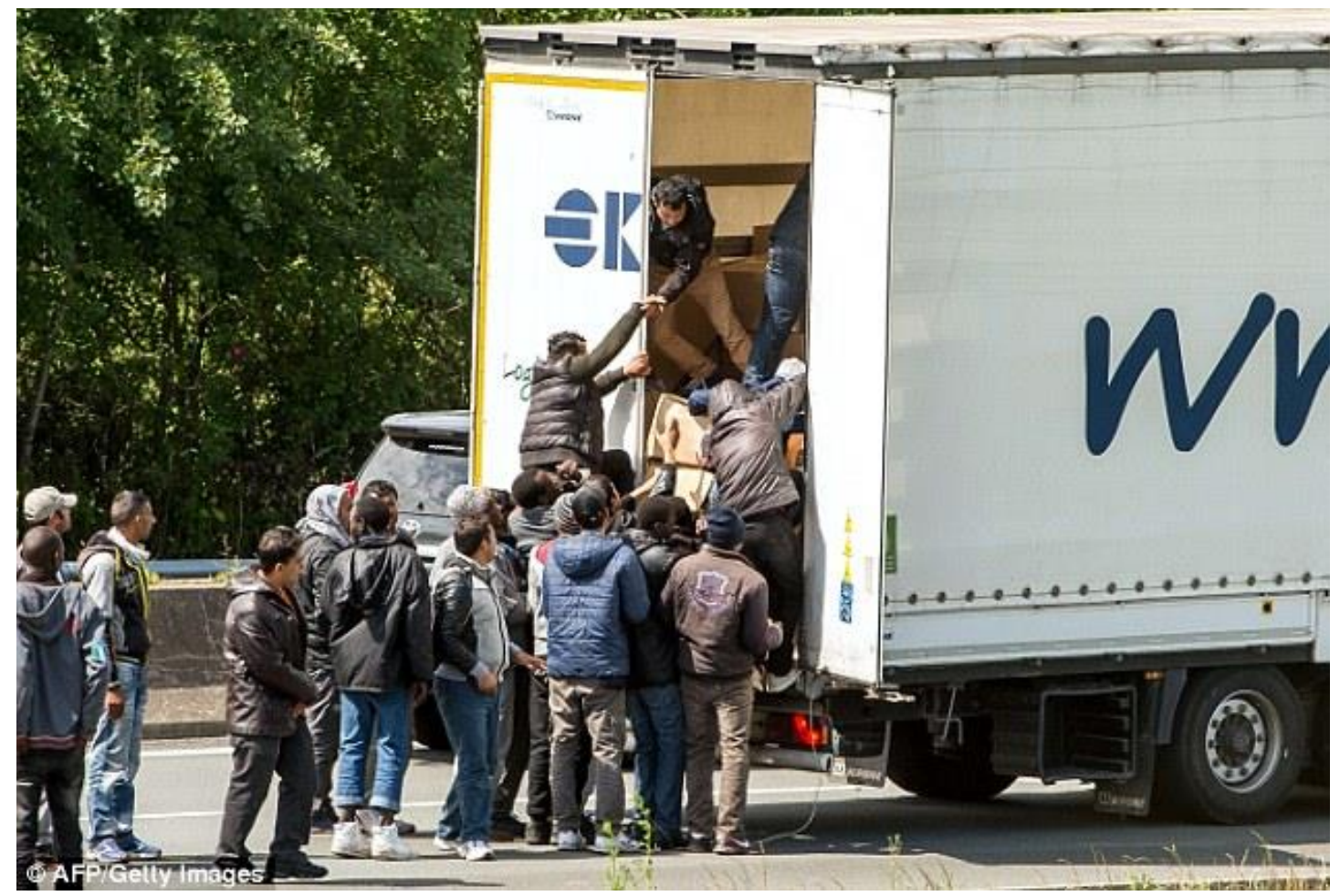

Figure 1 - Migrants climb in the back of a lorry on the highway leading to the Eurotunnel in Calais, northern France. Daily Mail, 26 June 2015

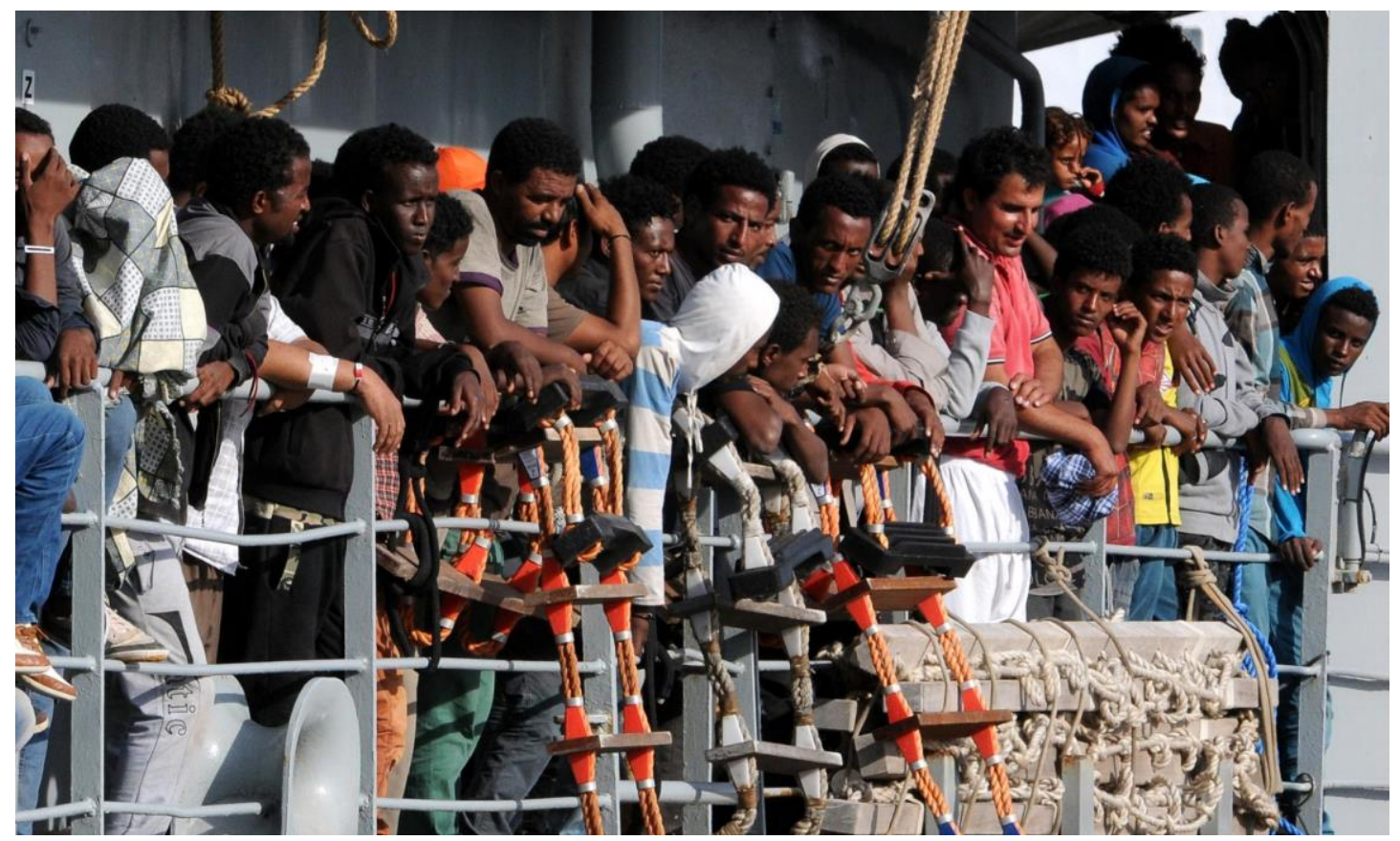

Figure 2 - Migrants wait to disembark from the Irish naval ship Le Eithne, at Palermo harbour, Italy. The Guardian, 1 July 2015

The images in both articles mirror and support the results of the textual analysis. Starting with the Daily Mail (Figure 1), the idea of a mass of people is conveyed through the portrayal of a group of 'migrants'. The angle of the image is of particular significance as it shows them from behind, making it more difficult for the viewer to 
identify with them - they are faceless figures, anonymous, an undifferentiated mass. Furthermore, the image is a long shot, which again reinforces distance. The distance from the camera, and the fact that the subjects have their backs turned as if they do not know they are being watched, aligns the image with the aesthetic of security surveillance footage. As the employment of security cameras is associated with keeping order, or in other words, to help prevent and prove criminal behaviour, this brings about associations with illegality. It is not explicitly stated in the image or caption that these are 'illegal' immigrants, but the idea is made implicit as they are portrayed as sneaking into Europe through concealment.

Of particular importance in the Daily Mail image is the 'transactional process' (Kress \& Van Leeuwen 1996, 64-65) being conveyed: the photo clearly portrays movement towards the lorry. The caption of the photo makes use of a transitive verb and gives the subjects agency by stating that they 'climb' into the lorry. The use of the present tense is also an impactful choice, suggesting that this problem is on-going, and is happening right now - thereby conveying a sense of urgency. The lorry in the image is located within Europe, as the caption tells us. The image used could therefore subtly reflect the common metaphor employed within 'migrant' discourse, which depicts illegal immigrants as entering Britain 'through the back door' (see for example: Ashworth 2010; Stolz 2000; Daily Mail 2013): this metaphor works in this image by depicting 'migrants' entering the literal back door of the lorry, and the 'back door' (Eurotunnel) of the UK. The metaphor is strengthened through the colours within the image frame. Whether implicitly or not, the contrast of the white lorry with the dark skin and dark clothes of the 'migrants' creates a striking effect. If the lorry is to represent Europe in this scenario, and the 'migrants' the unwelcome threat, the connotations of innocence and neutrality associated with the colour white, and the negative connotations of the colour black serve to reinforce a positive representation of 'us' and a negative representation of 'them'.

The image published in The Guardian (Figure 2) is in some ways the antithesis of the Daily Mail image; for example, the image depicts the 'non-transactional' (Kress \& Van Leeuwen 1996, 64) process of waiting. The verb 'wait' in the caption is intransitive, and suggests a passiveness despite the active voice. The agency of the subjects is taken away, as they are unable to simply disembark, indicating a curtailed free will; something/someone is keeping them on the ship. In line with this idea of limited agency, the metal bars of the ship confine the 'migrants' in one physical space until, we presume, someone with a higher authority allows them to disembark. The situation and the visual depiction of the bars can arguably resemble those within a prison. This idea of a prison could either hint at the perceived 'illegality' of migrants entering Europe by sea, or their victimhood - they are restrained until they reach Europe, where they can be liberated.

The camera in The Guardian image uses a medium-long shot, and shows the faces of the persons depicted, which makes it easier for the viewer to identify with them. Moreover, in contrast to the dark coloured clothes in the Daily Mail image, the colours of the clothes in this image stand out. In fact, we can notice that each person is wearing different clothes and different colours, highlighting a sense of individuality, drawing away from the homogeneous idea of the 'migrant'. However, just as with the description of 'migrants' in terms of numbers, the portrayal of them as 
a large mass of people in the image again detracts from the potential empathy of the viewer with the subjects.

As a final point for this analysis, I would like to highlight the gendered nature of the photos - they both consist solely of male migrants. In the context of humanitarianism, Heather Johnson points to the fact that "the image of a "Third World" mother and child became emblematic of "the refugee" (2011, 1030). This construction of the vulnerable refugee woman, she claims, is used as a tool for the mobilization of support behind humanitarian intervention and refugee work' $(2011,1032)$. There is much to be said in feminist terms about the vulnerable, voiceless, and passive image of the refugee being consistently associated with the female body, but it is also important to highlight the other side of this gendered association, namely the fact that men are mostly thought of as less vulnerable, less in need of protection, and as a potential threat. In relation to the images analysed here, the significance of gender then becomes more important if we combine it with the notion of 'choice', as highlighted in the textual analysis. These men are not described as refugees, but as 'migrants'; while the image of the refugee is predominantly female, the image of the 'migrant' tends to be predominantly male, as we see here. The Daily Mail image in fact portrays the men as having agency and looking tough, almost gang-like. In The Guardian, the men are also not portrayed as vulnerable, despite being passive; typical signifiers of submissiveness in body language, such as head down, lowered body, hunching inwards, crossing arms, etc. are not present in the immobile subjects. This would suggest that neither of the images intend to appeal to the sympathy of viewers. Such gender stereotyping in the discourse of 'asylum' can have real world consequences that make it more difficult for men to gain asylum, as Peter Mascini and Marjolein van Bochove (2009) discovered in their study of the Dutch asylum procedure.

One of the most interesting things about these articles is what is left out: they allude to the idea of criminality (the bars that make the boat look like a prison, the surveillance-like photo, the focus of the headlines on the points of entry) but the smuggling of 'migrants' is not addressed directly in the headlines. Interestingly, both articles seem to establish that (illegal) migration into Europe is dangerous, but in different ways: The Guardian goes on to talk about the death rate of migrants crossing the Mediterranean sea, while the Daily Mail focuses on the dangers that migrants pose to lorry drivers, Europe, and the UK. But again, this connection between illegal migration and danger is not made explicit in the headlines. It is quite telling that both headlines and images focus on how the migrants are arriving in Europe (boat/lorry/association with illegal migration), rather than who they are (the 'migrants' are instead reduced to a number or a 'wave') or why they come (we cannot know from the headline what makes them a 'threat' or what hardships they faced before their arrival).

So what effect does this have for the meaning of the articles if the reader, through the various signifiers used in the headlines and photos, understands the articles as being about the illegal entry of migrants at first glance, despite the omission of the word illegal? It arguably presumes that we already know the 'migrants' are travelling illegally. By presenting this type of (illegal) migration as a natural event or an objective truth, we are spared any reflection on our own role in creating the problem; 
we deflect the fact that our politics determines the classification of who is a 'illegal' immigrant, who is a legitimate refugee, and consequently, how we 'deal' with different categories of immigrants.

\section{Conclusion}

Due to the short length of this paper, the findings here are limited and show only a partial analysis of the representation of refugees within these two publications. Nevertheless by employing MCDA to the headlines and images of the articles, the following results were observed: although the two articles use different styles, i.e. the Daily Mail uses more emotive and sensationalist language than The Guardian, both articles convey authority: either by using objective language and high modality in the headline to present the story as fact (The Guardian) or by using the imperative to convey to the reader that the author has expertise in the subject (Daily Mail). The focus on Europe is also present in both articles: the problem is positioned further away, in the Mediterranean, or Southern Europe, which plays into Euro-sceptic sentiments. However, while The Guardian seems to depict the EU as a solution to the crisis, the Daily Mail points to the EU as a main culprit for its soft approach on migration. The images also have metaphorical meaning: The Daily Mail uses colour to create a contrast between the undesirable migrants dressed in black and the innocent lorry (representing the UK) painted in white, and also alludes to the aesthetic of security surveillance by choosing a rear angle for the photo, while in The Guardian, the bars of the ship convey the idea of a prison, alluding to illegality.

The representations of 'migrants' as natural disasters, criminals, victims and most importantly, as masses of people rather than individual humans, make it harder for the reader to identify with them. The camera in both photos is positioned far enough away for us to see the migrants as a large group, rather than capturing their emotions with close ups. Hegemonic gender power structures are also reinforced in this discourse through gendered representations of (illegal) 'migrants' as male, in contrast to the usual representation of legitimate refugee victims as female. Moreover, the word 'migrant' is used to describe the subjects in the image and headlines, conveying a different, and at first glance, more neutral meaning than if the words asylum seeker or refugee were used. Yet, despite the attempts to depoliticize the 'migrant', the label already implies there is agency and choice, a decision to migrate. By avoiding any reflection on the significance of such labelling processes, i.e. by using the word migrant to describe asylum seekers, refugees, and economic migrants alike, or by failing to discuss the fact that these people are entering 'illegally', the article masks certain power relations, namely the fact that 'we' have the power to define them, victimise them, criminalise them, confine them to designated spaces, save them, or incarcerate them, while they remain voiceless. Taking all of these findings into account, I would conclude that despite their different ideological stances, both The Guardian and the Daily Mail present the arrival of migrants in Europe negatively. They de-humanise migrants, apply gender stereotyping, construct Britain as separate from Europe while at the same time constructing Europe as separate from other regions from which the migrants come, and deflect the moral responsibility that this British or European 'we' might have towards refugees. However, further study is 
needed with larger samples and a deeper analysis of the discursive practices and social context to confirm these findings.

\section{References}

Allen, W. \& Blinder, S. (2013) Migration in the News: Portrayals of Immigrants, Migrants, Asylum Seekers and Refugees in National British Newspapers, 20102012, Oxford: Migration Observatory, COMPASS

Ashworth, R. (2010) 'Immigration: Britain through the back door', Express, [Online]. Available at http://www.express.co.uk/news/uk/193265/Immigration-Britainthrough-the-back-door. Accessed 8 July 2015

Baker, J. (2007) Discourses of refugees and asylum seekers in the UK press, 19962006: Full Research Report, Swindon: ESRC

Barnett, L. (2002) 'Global governance and the evolution of the international refugee regime', International Journal of Refugee Law, 14, April, 238-262

BBC (2015a) 'Calais migrant crisis leads to chaos in UK', BBC News, [Online]. Available at: http://www.bbc.com/news/uk-33709849. Accessed March 252016

BBC (2015b) 'Islamic State militants "smuggled to Europe"', BBC News, [Online]. Available at: http://www.bbc.com/news/world-africa-32770390. Accessed March 25 2016

BBC (2015) 'David Cameron criticised over migrant "swarm" language', BBC News, [Online], 30 July. Available at http://www.bbc.co.uk/news/uk-politics-33716501. Accessed 2 November 2015

Bowcher, W.L. (2007). New Directions in the Analysis of Multimodal Discourse, Psychology Press

Brokenshire, J. (2015) 'New action to make Britain a harder place for illegal migrants', GOV.UK, [Online]. Available at https://www.gov.uk/government/news/new-action-to-make-britain-a-harder-placefor-illegal-migrants. Accessed April 42016.

Burleigh, M. (2015) 'Forget the Greek crisis or Britain's referendum, this tidal wave of migrants could be the biggest threat to Europe since the war', Daily Mail, [Online], 26 June. Available at http://www.dailymail.co.uk/news/article-3141005/Tidal-wavemigrants-biggest-threat-Europe-war.html. Accessed 2 November 2015.

Chauvin, S. \& Garcés-Mascareñas, B. (2014) 'Becoming less illegal: Deservingness frames and undocumented migrant incorporation', Sociology compass, 8, 4, 422 432 
Cunha, E. (2013) 'The Daily Mail vs Mail Online', Journalism Now, [Online], 19 March. Available at http://www.journalism-now.co.uk/the-daily-mail-vs-mailonline/. Accessed 8 July 2015.

Fairclough, N. (1995a) Critical discourse analysis: The critical study of language, London: Longman

Flashnews UK (2009) 'Target audience facts', In the news, [Online], 20 October. Available at https://flashnewsuk.wordpress.com/2009/10/27/target-audience-facts/ Accessed 8 July 2015.

Gambino, L. (2015) '"No human being is illegal": linguists argue against mislabeling of immigrants', The Guardian, [Online]. Available at:

http://www.theguardian.com/us-news/2015/dec/06/illegal-immigrant-labeloffensive-wrong-activists-say. Accessed April 42016.

Goodman, S. \& Speer, S.A. (2007) 'Category Use in the Construction of Asylum Seekers', Critical Discourse Studies, 4, 2,165-185.

The Guardian (2011) 'The Guardian's Editorial Code', The Guardian, [Online]. Available at http://www.theguardian.com/info/guardian-editorial-code. Accessed 8 July 2015.

The Guardian (2014) 'The Guardian view on rising illegal immigration', The Guardian, [Online], 4 Aug. Available at http://www.theguardian.com/commentisfree/2014/aug/04/guardian-view-risingillegal-immigration. Accessed 9 July 2015.

Hilsum, L. (2015) 'Migrants or refugees: what's the right word?', Channel 4 blogs, [Online]. Available at: http://blogs.channel4.com/lindsey-hilsum-on-internationalaffairs/migrants-refugees-word/5487. Accessed April 32016.

Hopkins, K. (2015) 'Rescue boats? I'd use gunships to stop illegal migrants', Sun Nation, [online]. Available at: http://www.sunnation.co.uk/hopkins-rescue-boats-iduse-gunships-to-stop-illegal-migrants/. Accessed July 92015.

Johnson, H.L. (2011) 'Click to Donate: visual images, constructing victims and imagining the female refugee', Third World Quarterly, 32, July, 1015-1037

Jones, R.H. (2012) 'Multimodal Discourse Analysis' In Carol A. Chapelle,(eds), The Encyclopedia of Applied Linguistics, Iowa: Blackwell Publishing

Koutonin, M.R. (2015) 'Why are white people expats when the rest of us are immigrants?', The Guardian, [Online]. Available at: http://www.theguardian.com/global-development-professionalsnetwork/2015/mar/13/white-people-expats-immigrants-migration. Accessed April 3 2016.

Kress, G.R. \& Van Leeuwen, T. (1996) Reading images: The grammar of visual design, London: Routledge 
Kress, G. \& Van Leeuwen, T. (2002) 'Colour as a semiotic mode: Notes for a grammar of colour', Visual communication, 1, October, 343-368

Lenart, J. (2012) 'Fortress Europe': Compliance of the Dublin II Regulation with the European Convention for the Protection of Human Rights and Fundamental Freedoms. Merkourios, 28, 75, 4-19

LeVine, P. \& Scollon, R. (2004) Discourse and Technology: Multimodal Discourse Analysis, Washington D.C.: Georgetown University Press

Machin, D. \& Mayr, A. (2012) How to do critical discourse analysis: A multimodal introduction, London: Sage.

Daily Mail, 'Contact Us', Daily Mail, [Online]. Available at http://www.dailymail.co.uk/home/article-1227210/Contact-Us.html Accessed 2 November 2015

Daily Mail, 'New EU rules “could open immigration backdoor”', Daily Mail, [Online]. Available at http://www.dailymail.co.uk/news/article-159951/New-EUrules-open-immigration-backdoor.html. Accessed 3 November 2015

Malone, B., (2015) 'Why Al Jazeera will not say Mediterranean "migrants"', Al Jazeera, [Online]. Available at http://www.aljazeera.com/blogs/editorsblog/2015/08/al-jazeera-mediterranean-migrants-150820082226309.html. Accessed April 32016

Marsh, D. (2015) 'We deride them as "migrants'". Why not call them people?', The Guardian, [Online]. Available at http://www.theguardian.com/commentisfree/2015/aug/28/migrants-people-refugeeshumanity. Accessed April 3, 2016

Mascini, P. \& Van Bochove, M. (2009) 'Gender Stereotyping in the Dutch Asylum Procedure:"Independent" Men versus "Dependent" Women', International Migration Review, 43, March, 112-133

Massey, R. et al. (2015) 'Channel travel chaos continues with 15,000 train passengers affected', Daily Mail, [Online]. Available at http://www.dailymail.co.uk/news/article-3137213/Calais-travel-chaos-migrantstarget-lorries-bid-smuggle-Britain.html. Accessed 2 November 2015

Melissaris, E. (2016) 'Legal dehumanising: on the arrest of refugee solidarity activists', OpenDemocracy, [Online]. Available at https://www.opendemocracy.net/can-europe-make-it/emmanuel-melissaris/legaldehumanising-on-arrest-of-refugee-solidarity-activists. Accessed April 42016

Paul, A. (2016) Turkey makes a mockery of Europe's claim to uphold democratic values, European Policy Centre

Philo, G., Briant, E. \& Donald, P. (2013) Bad news for refugees, London: Pluto 
Reid, A. (2014) 'Report: Guardian sees most monthly web-only UK readers', Journalism, [Online]. Available at https://www.journalism.co.uk/news/reportguardian-maintains-lead-with-most-monthly-web-only-uk-readers/s2/a562273/. Accessed 3 November 2015

Richardson, J.E. (2007) Analysing newspapers: An approach from critical discourse analysis, Basingstoke: Palgrave Macmillan

Ropeik, D. (2011) 'Statistical Numbing: Why Millions Can Die and We Don't Care', Psychology Today, [Online], 15 August. Available at https://www.psychologytoday.com/blog/how-risky-is-it-really/201108/statisticalnumbing-why-millions-can-die-and-we-don-t-care. Accessed 2 November 2015.

Schulzek, N. (2012) 'The impact of welfare systems on immigration: An analysis of welfare magnets as a pull-factor for asylum seekers and labour migrants', $L S E$ Migration Studies Unit, 2

Schweppe, C. \& Sharma, N. (2015) 'Borders - transborders - no borders: Problematizing the "Figure of the migrant"', Transnational Social Review, 5, 1, 2-6

Stolz, G. (2000) 'Europe's Back Doors', The Atlantic, [Online], January. Available at http://www.theatlantic.com/magazine/archive/2000/01/europes-back-doors/377965/. Accessed 3 November 2015

Swinford, S. (2015) Millions of African migrants threaten standard of living, Philip Hammond says, The Telegraph, [Online]. Available at http://www.telegraph.co.uk/news/uknews/immigration/11792798/Millions-ofAfrican-migrants-threaten-standard-of-living-Philip-Hammond-says.html. Accessed March 252016

Taylor, M. (2015) 'Calais migrants: "we have to keep trying because this is no place to stay.", The Guardian, [Online], 24 June. Available at http://www.theguardian.com/world/2015/jun/24/calais-migrants-keep-trying-franceuk. Accessed 3 november 2015

The Guardian (2015a) 'Immigration special', The Guardian, [Online]. Available at http://www.theguardian.com/commentisfree/series/immigration-special. Accessed 3 November 2015

The Guardian, (2015b) Net migration to UK hits record high of 330,000. The Guardian. Available at http://www.theguardian.com/uk-news/2015/aug/27/netmigration-predicted-to-hit-record-level. Accessed March 252016

The Guardian (2015b) 'Numbers of migrants crossing Mediterranean nearly doubles in a year', The Guardian, [Online], 1 July. Available at http://www.theguardian.com/world/2015/jul/01/migrant-crisis-mediterraneannumbers-nearly-double Accessed 3 November 2015

The Migration Observatory, (2015) 'Who Counts as a Migrant? Definitions and their Consequences', Migration Observatory, [Online]. Available at 
http://www.migrationobservatory.ox.ac.uk/briefings/who-counts-migrantdefinitions-and-their-consequences. Accessed March 252016

Turton, D. (2003) 'Conceptualising forced migration', Refugee Studies Centre Working Paper, 12, October Available at http://www.rsc.ox.ac.uk/files/publications/working-paper-series/wp12conceptualising-forced-migration-2003.pdf

UNHCR, (2011) The 1951 Convention relating to the Status of Refugees and its 1967 Protocol, Geneva. Available at http://www.unhcr.org/4ec262df9.html. Accessed March 252016

UNHCR, (2015) UNHCR report shows world's poorest countries host most refugees. UNHCR RRCE. Available at http://unhcr-centraleurope.org/en/news/2015/unhcrreport-shows-worlds-poorest-countries-host-most-refugees.html. Accessed April 3 2016

Whitehead, T., (2015) 'Calais crisis: Fears Isil may use migrant chaos to slip jihadists in to UK', The Telegraph [Online]. Available at http://www.telegraph.co.uk/news/uknews/immigration/11695862/Calais-crisisFears-Isil-may-use-migrant-chaos-to-slip-jihadists-in-to-UK.html. Accessed March 252016

Zetter, R. (2007) 'More Labels, Fewer Refugees: Remaking the Refugee Label in an Era of Globalization', Journal of Refugee Studies, 20, June, 172-192

Carolina Silveira is a postgraduate student working towards the MA in Research Training in Social Sciences at Humboldt Universität, Berlin. She received an MA in Contemporary European Studies (Euromasters) from the University of Bath in 2014, and a Bachelor in German and Spanish Language and Culture from the University of Edinburgh in 2012. She has previously published the article 'Youth as Political Actors after the 'Arab Spring' - The Case of Tunisia' (Silveira, 2015), and participated in a conference by the Heinrich Böll Foundation on the same topic: 'Yallah! Jugend und politische Teilhabe in Nordafrika'. In November 2015, she will also participate in the ECREA Conference: Diaspora, Migration and the Media, in Rotterdam. Carolina's research interests include discourse analysis, migration, and the representation of refugees in the news. She is currently concluding her MA thesis on the use of Discourse Analysis for interdisciplinary research in Social Sciences, and plans to conduct her PHD on the refugee discourse in media and politics in the UK and Brazil.

Email: carolina.cm.silveira@gmail.com 